\title{
PCR-BASED METHODS TO THE DIAGNOSIS OF IMPORTED MALARIA
}

\author{
BERRY A.*, BENOIT-VICAL F.***, FABRE R.*, CASSAING S.* \& MAGNAVAL J.F.*
}

\section{Summary:}

Rapid and precise diagnosis of malaria is needed to take care febrile patient returning from endemic areas. Since the first description of the diagnosis of Plasmodium infection by polymerase-chain-reaction (PCR), the role of this kind of molecular method in the laboratory diagnosis of imported malaria is still a topical question. PCR-based assays were found to be more sensitive and more specific than all conventional methods. The highest contribution of the molecular diagnosis is that a PCR negative result would ascertain the lack of any malaria infection, thus quickly orienting the investigations toward other aetiology. This technique should be now considered as the gold standard for the diagnosis of imported malaria.

KEY WORDS : imported malaria, molecular diagnosis, PCR

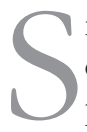
ince the first description, in 1990, of the diagnosis of Plasmodium falciparum infection by means of polymerase-chain-reaction (PCR) (Jaureguiberry et al., 1990), the role of this kind of molecular method in the laboratory diagnosis of imported malaria is still a topical question. Albeit considered the gold standard as regards sensitivity and specificity, the use of PCRbased assays for routine detection of malaria infection is debatable for many people, who consider the practical requirements (expensive apparatus, need for qualified technicians, usage costs), together with the risk of contamination and the problems of emergency diagnosis, to be out of proportion given the known benefits. However, permanent technological improvement has made PCR faster and more and more user-friendly.

\section{A SENSITIVE ASSAY}

F or the laboratory diagnosis of malaria, PCR-based assays were found to be more sensitive than all conventional methods, whatever the type of PCR-

* Service de Parasitologie-Mycologie, Hôpital Rangueil, Centre Hospitalier Universitaire de Toulouse, TSA 50032, 31059 Toulouse 9, France.

** Laboratoire de Chimie de Coordination du CNRS, 205, route de Narbonne, 31077 Toulouse 4, France.

Correspondence: Antoine Berry.

Tel.: 33 (0)5 61322892 - Fax: 33 (0)5 61322096

E-mail: berry.a@chu-toulouse.fr based test used (see above) or the nature of primers that were used. At its best, the power of detection of thick blood smear examination ranged from 10 to 50 parasites/ $\mathrm{LL}$ (Guerin et al., 2002; Moody, 2002). Quantitative Buffy Coat $\left(\mathrm{QBC}^{\circledR}\right)$ tests were not more efficient (Wongsrichanalai et al., 1991) and dipstick assays exhibited a poor sensitivity when the parasitemia value was under 100 parasites/ $\mu \mathrm{L}$ (Moody, 2002). Conversely, in 20 studies (Table I), PCR's sensitivity for the detection of $P$. falciparum ranged from 0.004 to 30 parasites/ $\mu \mathrm{L}$. However, some of these results should be carefully considered, since they were experimental and dilution ranges were done in very different manners, using either blood from infected subjects, or from $P$. falciparum cultivation (often with no indication concerning synchronization, so the presence of multinucleated schizonts might be suspected), or from extracted DNA (with different methods of extraction). For species other than $P$. falciparum, comparing sensitivity results were impossible due to the lack of any means of cultivation and also to the variation of the proportion of schizonts between different patients.

Concerning the diagnosis of imported malaria, only papers that compared PCR and conventional microscopy during a limited period of time and in all patients suspected to be infected were analyzed. In 15 studies including 2,416 subjects, 1,108 patients were found to be malaria positive by conventional microscopy, and $1,204(+10 \%)$ by PCR (range: from 0 to $+13 \%$ ). All the patients positive by microscopy were also positive by PCR, whatever the Plasmodium species. When compared to the set of the requests, the gain of sensitivity was $4.4 \%$ (range: from 0 to $+11 \%$ ) (Rubio et al., 1999; Filisetti et al., 2002; Morassin et al., 2002; Richardson et al., 2002; de Monbrison et al., 2003; Padley et al., 2003; Patsoula et al., 2003; Perandin et al., 2003; Calderaro et al., 2004; Fabre et al., 2004; Perandin et al., 2004; Rougemont et al., 2004; Whiley et al., 2004; Machouart et al., 2006; Vo et al., 2007). This improvement in sensitivity affected mainly falciparum malaria. $P$. falciparum is the most frequently detected agent of imported malaria, especially in the European Union where the closest endemic zone is sub-Saharan Africa (Jelinek et al., 2002). Moreover, even chemoprophy- 


\begin{tabular}{|c|c|c|c|c|c|c|}
\hline Authors/Year & Apparatus & $\begin{array}{l}\text { PCR } \\
\text { type }\end{array}$ & Revelation & Detected species ${ }^{1}$ & $\begin{array}{c}\text { Gene's } \\
\text { target }\end{array}$ & $\begin{array}{c}\text { Sensitivity } \\
\text { for } P f \\
\text { (parasite/ } \mu \mathrm{l} \text { ) }\end{array}$ \\
\hline Arai et al., 1994 & Classical & Nested & Ethidium bromide (gel) & $P f$ & DHFR & 1.3 \\
\hline Ciceron et al., 1999 & Classical & Simplex & Probe (southern blot) & Genus $P f, P v /$ & SSUrRNA & 3.0 \\
\hline Tham et al., 1999 & Classical & Simplex & Probe (gel) & Genus $P f, P o, P v /$ & Cox 1/Plastid & 0.01 \\
\hline Fabre et al., 2002 & Real-time & $\begin{array}{l}\text { Multiplex } \\
\text { \& simplex }{ }^{2}\end{array}$ & Syber green ${ }^{\circledR}$ & Genus/Pm & $\begin{array}{l}\text { Cox 1/Plastid/ } \\
\text { SSUrRNA }\end{array}$ & 0.035 \\
\hline Filisetti et al., 2002 & Classical & Simplex & Ethidium bromide (gel) & $P f$ & STEVOR & 0.01 \\
\hline Myjak et al., 2002 & Classical & Nested & Ethidium bromide (gel) & 4 & SSUrRNA & 0.38 \\
\hline Rubio et al., 2002 & Classical & $\begin{array}{l}\text { Nested \& } \\
\text { multiplex }\end{array}$ & Ethidium bromide (gel) & 4 & SSUrRNA & 0.01 \\
\hline De Monbrison et al., 2003 & Real-time & Simplex & Syber green ${ }^{\circledR}$ & Genus \& 4 & SSUrRNA & 30 \\
\hline Kho et al., 2003 & Classical & Multiplex & Ethidium bromide (gel) & $P f, P v$ & SSUrRNA & 0.1 \\
\hline Patsoula et al., 2003 & Classical & Multiplex & Ethidium bromide (gel) & $P f, P v$ & SSUrRNA & 1.0 \\
\hline Calderaro et al., 2004 & Classical & Nested & Probe (enzyme-linked) & 4 & SSUrRNA & 0.07 \\
\hline McNamara et al., 2004 & Classical & Simplex & Probe (gel) & 4 & SSUrRNA & 0.1 \\
\hline Montenegro et al., 2004 & Classical & Nested & Ethidium bromide (gel) & Genus & SSUrRNA & 0.07 \\
\hline Perandin et al., 2004 & Real-time & Simplex & Probe & $P f, P o, P v$ & SSUrRNA & 1.0 \\
\hline Whiley et al., 2004 & Classical & Simplex & Probe (enzyme-linked) & 4 & SSUrRNA & 1.4 \\
\hline Mangold et al., 2005 & Real -time & Simplex & Syber green ${ }^{\circledR}$ & 4 & SSUrRNA & 1.0 \\
\hline Elsayed et al., 2006 & Real-time & Simplex & Probe (molecular braecon) & $P f$, Genus & $\begin{array}{l}\text { Cox 1/Plastid/ } \\
\text { SSUrRNA }\end{array}$ & 0.004 \\
\hline Machouart et al., 2006 & Classical & Simplex & Probe (enzyme-linked) & 4 & SSUrRNA & 10 \\
\hline Vo et al., 2007 & Real Time & Simplex & Syber green & 4 & $\begin{array}{l}\text { AQP/ECPR, } \\
\text { Pos } 25 / C S\end{array}$ & 15 \\
\hline \multirow[t]{2}{*}{ Gama et al., 2007} & Real time & Simplex & Probe $\left(\right.$ TaqMan $\left.^{\circledR}\right)$ & $P f$ & SSUrRNA & 0.5 \\
\hline & Classical & Simplex & Ethidium bromide (gel) & $P f$ & SSUrRNA & 0.5 \\
\hline
\end{tabular}

${ }^{1} P f$, Pm, Po, Pv: Plasmodium falciparaum, P. malariae, P. ovale, P. vivax.

${ }^{2}$ For $P m, P O, P v$.

Table I. - PCR's sensitivity for the detection of P. falciparum ranged from 0.004 to 30 parasites/ $\mu \mathrm{L}$ in 20 studies.

laxis that is not correctly followed out remains rather active on species other than $P$. falciparum, apart from the chloroquine-resistant $P$. vivax strains, which are still rarely encountered in Europe.

\section{A SPECIFIC METHOD}

T The nature of the target for primers or probes, as determined by the studies of the Plasmodium genome whose results are available in GenBank $^{\circledR}$, guarantees the specificity of PCR results. A further precaution has often been the sequencing of PCR products.

Concerning Plasmodium species identification, literature analysis reports frequent and sometimes substantial discrepancies between the results from microscopy and those from PCR. From the last 12 published studies that have compared the performance of thin blood smear examination and PCR, $17.1 \%$ (range: $1.5-39$ ) of 923 species identifications by microscopy were corrected after PCR checking (Rubio et al., 1999; Morassin et al., 2002; de Monbrison et al., 2003; Perandin et al., 2003; Calderaro et al., 2004; Di Santi et al., 2004; Ndao et al., 2004; Perandin et al., 2004; Rougemont et al., 2004; Whiley et al., 2004; Machouart et al., 2006; Vo et al., 2007). The rate of misdiagnosis varied from $20 \%$ to $50 \%$ for $P$. malariae, $P$. ovale or $P$. vivax (Morassin et al., 2002; de Monbrison et al., 2003; Perandin et al., 2003; Calderaro et al., 2004; Di Santi et al., 2004; Ndao et al., 2004; Perandin et al., 2004; Rougemont et al., 2004). Concerning mixed infections, practically $100 \%$ of the microscopy results were false, either by excess (diagnostic of a mixed infection when there was a single species) or by omission (reverse situation). Plasmodium falciparum identification appeared to be more reliable, with no misdiagnoses found in eight studies (Morassin et al., 2002; de Monbrison et al., 2003; Calderaro et al., 2004; Ndao et al., 2004; Perandin et al., 2004; Whiley et al., 2004; Machouart et al., 2006; Vo et al., 2007), a 1.7 to $2.8 \%$ misdiagnosis rate in three studies (Rougemont et al., 2004; Rubio et al., 1999; Perandin et al., 2003) and $8.4 \%$ of misdiagnoses in one study (Di Santi et al., 2004).

However, the high specificity of PCR methods demonstrated the other side of the coin, namely the intrinsic risk of these tests being unable to detect new molecular variants. This phenomenon was reported concerning $P$. malariae in China (Liu et al., 1998; Kawamoto et al., 2002), P. ovale in the Thai - Myanmar border region (Kawamoto et al., 1996) or in Africa (Calderaro et al., 2007) and also P. vivax in Papua-New Guinea, where the so-called $P$. vivax-like species was described (Qari et al., 1993). Moreover, newly emergent infec- 
tions by zoonotic primate Plasmodium can go undiagnosed by species-PCR, which occurred with the Borneo focus of P. knowlesi (Singh et al., 2004).

When primers or probes are chosen then designed, these two points should be kept in mind and correlated with future uses of the PCR test, e.g. routine diagnosis in a westernized country or, conversely, epidemiology surveys from specimens collected in the field. The concomitant use of an assay detecting the Plasmodium genus, whatever the origin - Man, subhuman primate or even rodent - of the species involved, appears to be an excellent safeguard against rare but possible false negative results.

\section{PCR AND THE DIAGNOSIS OF IMPORTED MALARIA}

E ven now, PCR assay may be considered the gold standard for the diagnosis of malaria, therefore $\checkmark$ replacing thick smear examination. This situation is due to both high sensitivity and specificity, as detailed above. While PCR is used more and more in laboratories of Parasitology, its exact place in the full range of malaria diagnostic tests has yet to be explicitly established.

Obviously, the emergency diagnosis of malaria will for a long time remain the prerogative of microscopy (thin smear or fast thick smear examination (Thellier et al., 2002), $\mathrm{QBC}^{\circledR}$ ) associated with immunochromatographic methods. Such a test combination can detect all infections displaying a moderate to high parasitemia, which ensures within less than half an hour the diagnosis of severe malaria. PCR should therefore be considered a second-line method.

The first question about the routine use of PCR for the diagnosis of imported malaria concerns the schedule of use, daily, weekly or bimonthly, and also the type of specimens concerned, all or only those posing a problem. Based on a 8-year experience, we subsequently believe PCR should be done on a daily basis. In this case, low parasitemia infections due to, e.g. incorrect chemoprophylaxis or an immune status, would be promptly identified, despite having escaped the firstline methods. Anyone who deals with tropical medicine has had a personal example of a patient displaying chronic fever along with a recent history of travel in a malaria-endemic area and who is finally diagnosed as malaria-infected after many days of hospitalization and multiple conventional investigations. A request for PCR would quickly resolve this diagnostic quandary (Puente et al., 2000; Antinori et al., 2001; Speers et al., 2003). Moreover, it should be underlined that, according to our experience, the predictive negative value of a PCR-based result is $100 \%$. A negative result would ascertain the lack of any malaria infection, thus quickly orienting the investigations toward other hypotheses. With the expected reduction of hospitalization time, substantial money saving could be achieved, as - in France - daily costs are approximately $800 €$ in a Department of Internal Medicine or Infectious/Tropical Diseases. Parasitemia level can be quantified by real-time PCR. However, this can be more easily achieved by the combined use of blood count results and thin smear examination.

Since real-time PCR can detect and quantify very low parasitic loads, it has been hypothesized that this assay could be a valuable tool for the monitoring of falciparum malaria therapy. Two studies indicated that the persistence of positive PCR results after a 5-day treatment was consistent with treatment failure (Kain et al., 1994; Ciceron et al., 1999). However, such a result can also be due to the presence of gametocytes (Smalley $\&$ Sinden, 1977), which removes any purpose from this kind of molecular follow-up.

From a financial point of view, PCR is said to be a costly method. It is clear that technical requirements, such as room layout in a laboratory, together with the purchase of a thermocycler and the required ancillaries, are not inexpensive. However, one should consider that this price is on a constantly decreasing slope and these investments are also indispensable for other diagnoses in Parasitology, such as that of congenital toxoplasmosis. Many hospitals have also chosen the solution of a technical platform pooled with different laboratories. In fine, it appears obvious that PCR use improves the diagnosis of imported malaria, but also that this method is restricted to health centers, such as University Hospitals, for whom malaria identification is an important and routine problem. For other structures, the combination of conventional microscopy with immunochromatographic methods is certainly the best choice.

\section{CONCLUSION}

\begin{abstract}
urrently, PCR assay may be considered the "gold standard" for malaria diagnosis, given both its high sensitivity and specificity, along with the robust predictive value of a negative result. PCR-based methods should therefore be included in the panel of diagnostic tools for imported malaria infection for any center of reference. This is based on both scientific reasons and also interesting from a "service" point of view, whose importance is constantly increasing, to help meet the duty of best efforts.
\end{abstract}

\section{REFERENCES}

Antinori S., Piazza M., Calattini S., Galazzi M., Scalamogna C., Pizzuto M. \& Corbellino M. Subacute malaria due to Plas- 
modium falciparum and the role of polymerase chain reaction. Clinical Infectious Diseases, 2001, 33, 1614-1615.

Arai M., Mizukoshi C., Kubochi F., Kakutani T. \& Wataya Y. Detection of Plasmodium falciparum in human blood by a nested polymerase chain reaction. American Journal of Tropical Medicine and Hygiene, 1994, 51, 617-626.

Calderaro A., Piccolo G., Perandin F., Gorrini C., Peruzzi S., Zuelli C., Ricci L., Manca N., Dettori G., Chezzi C. \& SnouNOU G. Genetic polymorphisms influence Plasmodium ovale PCR detection accuracy. Journal of Clinical Microbiology, 2007, 45, 1624-1627.

Calderaro A., Piccolo G., Zuelli C., Galati L., Ricci L., Perandin F., Dell'Anna M.L., Arcangeletti M.C., Medici M.C., Manca N., DetTori G. \& Chezzi C. Evaluation of a new plate hybridization assay for the laboratory diagnosis of imported malaria in Italy. The New Microbiologica, 2004, 27, 163171.

Ciceron L., Jaureguiberry G., Gay F. \& Danis M. Development of a Plasmodium PCR for monitoring efficacy of antimalarial treatment. Journal of Clinical Microbiology, 1999, 37, 35-38.

de Monbrison F., Angei C., Staal A., Kaiser K. \& Picot S. Simultaneous identification of the four human Plasmodium species and quantification of Plasmodium DNA load in human blood by real-time polymerase chain reaction. Transaction of the Royal Society of Tropical Medicine and Hygiene, 2003, 97, 387-390.

Di Santi S.M., Kirchgatter K., Brunialti K.C., Oliveira A.M., FerReIra S.R. \& Boulos M. PCR-based diagnosis to evaluate the performance of malaria reference centers. Revista do Instituto de Medicina Tropical de Sao Paulo, 2004, 46, 183187.

Elsayed S., Plewes K., Church D., Chow B. \& Zhang K. Use of molecular beacon probes for real-time PCR detection of Plasmodium falciparum and other Plasmodium species in peripheral blood specimens. Journal of Clinical Microbiology, 2006, 44, 622-624.

Fabre R., Berry A., Morassin B. \& Magnaval J.F. Comparative assessment of conventional PCR with multiplex realtime PCR using SYBR Green I detection for the molecular diagnosis of imported malaria. Parasitology, 2004, 128, 1521.

Filisetti D., Bombard S., N'Guiri C., Dahan R., Molet B., AbouBacar A., Hansmann Y., Christmann D. \& Candolfi E. Prospective assessment of a new polymerase chain reaction target (STEVOR) for imported Plasmodium falciparum malaria. European Journal of Clinical Microbiology and Infectious Diseases, 2002, 21, 679-681.

Gama B.E., Silva-Pires Fdo E., Lopes M.N., Cardoso M.A., Britto C., Torres K.L., De Mendonca Lima L., De Souza J.M., Daniel-Ribeiro C.T. \& Ferreira-DA-Cruz Mde F. Real-time PCR versus conventional PCR for malaria parasite detection in low-grade parasitemia. Experimental Parasitology, 2007, 116, 427-432.

Guerin P.J., Olliaro P., Nosten F., Druilhe P., Laxminarayan R., Binka F., Kilama W.L., Ford N. \& White N.J. Malaria: current status of control, diagnosis, treatment, and a proposed agenda for research and development. Lancet Infectious Diseases, 2002, 2, 564-573.
Jaureguiberry G., Hatin I., D’Auriol L. \& Galibert G. PCR detection of Plasmodium falciparum by oligonucleotide probes. Molecular and Cellular Probes, 1990, 4, 409-414.

Jelinek T., Schulte C., Behrens R., Grobusch M.P., Coulaud J.P., Bisoffi Z., Matteelli A., Clerinx J., Corachan M., Puente S., Gjorup I., Harms G., Kollaritsch H., Kotlowski A., Bjorkmann A., Delmont J.P., Knobloch J., Nielsen L.N., Cuadros J., Hatz C., Beran J., Schmid M.L., Schulze M., Lopez-Velez R., Fleischer K., Kapaun A., McWhinney P., Kern P., Atougia J., Fry G., da Cunha S. \& Boecken G. Imported Falciparum malaria in Europe: sentinel surveillance data from the European network on surveillance of imported infectious diseases. Clinical Infectious Diseases, 2002, 34, 572-576.

Kain K.C., Kyle D., Wongsrichanalai C., Brown A.E., Webster H.K., Vanijanonta S. \& Looareesuwan S. Qualitative and semiquantitative polymerase chain reaction to predict Plasmodium falciparum treatment failure. Journal of Infectious Diseases, 1994, 170, 1626-1630.

Kawamoto F., Miyake H., Kaneko O., Kimura M., Nguyen T.D., NguYen T.D., Liu Q., Zhou M., Le D.D., Kawai S., Isomura S. \& WATAYA Y. Sequence variation in the $18 \mathrm{~S}$ rRNA gene, a target for PCR-based malaria diagnosis, in Plasmodium ovale from southern Vietnam. Journal of Clinical Microbiology, 1996, 34, 2287-2289.

Kawamoto F., Win T.T., Mizuno S., Lin K., Kyaw O., TantuLART I.S., Mason D.P., Kimura M. \& Wongsrichanalai C. Unusual Plasmodium malariae-like parasites in southeast Asia. Journal of Parasitology, 2002, 88, 350-357.

Kho W.G., Chung J.Y., Sim E.J., Kim M.Y., Kim D.W., JongWUTIWES S. \& TANABE K. A multiplex polymerase chain reaction for a differential diagnosis of Plasmodium falciparum and Plasmodium vivax. Parasitology International, 2003, 52, 229-236.

Liu Q., Zhu S., Mizuno S., Kimura M., Liu P., Isomura S., Wang X. \& Kawamoto F. Sequence variation in the small-subunit rRNA gene of Plasmodium malariae and prevalence of isolates with the variant sequence in Sichuan, China. Journal of Clinical Microbiology, 1998, 36, 3378-3381.

Machouart M., Bigois-Delemotte L., Ajana F., Brizion M., Biava M.F., Collomb J. \& Fortier B. Development of a PCR assay followed by nonradioactive hybridization using oligonucleotides covalently bound to CovaLink NH microwells for detection of four Plasmodium species in blood samples from humans. Journal of Clinical Microbiology, 2006, 44, 3279-3284.

Mangold K.A., Manson R.U., Koay E.S., Stephens L., Regner M., Thomson R.B. Jr, Peterson L.R. \& Kaul K.L. Real-time PCR for detection and identification of Plasmodium spp. Journal of Clinical Microbiology, 2005, 43, 2435-2440.

McNamara D.T., Thomson J.M., Kasehagen L.J. \& Zimmerman P.A. Development of a multiplex PCR-ligase detection reaction assay for diagnosis of infection by the four parasite species causing malaria in humans. Journal of Clinical Microbiology, 2004, 42, 2403-2410.

Montenegro L.M., Montenegro R.A., Lima A.S., Carvalho A.B., Schindler H.C. \& Abath F.G. Development of a single tube hemi-nested PCR for genus-specific detection of Plasmodium in oligoparasitemic patients. Transaction of 
the Royal Society of Tropical Medicine and Hygiene, 2004, 98, 619-625.

Moody A. Rapid diagnostic tests for malaria parasites. Clinical Microbiology Review, 2002, 15, 66-78.

Morassin B., Fabre R., Berry A. \& Magnaval J.F. One year's experience with the polymerase chain reaction as a routine method for the diagnosis of imported malaria. American Journal of Tropical Medicine and Hygiene, 2002, 66, 503-508.

Myjak P., Nahorski W., Pieniazek N.J. \& Pietkiewicz H. Usefulness of PCR for diagnosis of imported malaria in Poland. European Journal of Clinical Microbiology and Infectious Diseases, 2002, 21, 215-218.

Ndao M., Bandyayera E., Kokoskin E., Gyorkos T.W., MacLEAN J.D. \& WARD B.J. Comparison of blood smear, antigen detection, and nested-PCR methods for screening refugees from regions where malaria is endemic after a malaria outbreak in Quebec, Canada. Journal of Clinical Microbiology, 2004, 42, 2694-2700.

Padley D., Moody A.H., Chiodini P.L. \& Saldanha J. Use of a rapid, single-round, multiplex PCR to detect malarial parasites and identify the species present. Annals of Tropical Medicine and Parasitology, 2003, 97, 131-137.

Patsoula E., Spanakos G., Sofianatou D., Parara M. \& Vakalis N.C. A single-step, PCR-based method for the detection and differentiation of Plasmodium vivax and P. falciparum. Annals of Tropical Medicine and Parasitology, 2003, 97, 15-21.

Perandin F., Manca N., Calderaro A., Piccolo G., Galati L., Ricci L., Medici M.C., Arcangeletti M.C., Snounou G., DetTORi G. \& CHezzi C. Development of a real-time PCR assay for detection of Plasmodium falciparum, Plasmodium vivax, and Plasmodium ovale for routine clinical diagnosis. Journal of Clinical Microbiology, 2004, 42, 1214-1219.

Perandin F., Manca N., Piccolo G., Calderaro A., Galati L., Ricci L., Medici M.C., Arcangeletti C., Dettori G. \& Chezzi C. Identification of Plasmodium falciparum, P. vivax, $P$. ovale and $P$. malariae and detection of mixed infection in patients with imported malaria in Italy. The New Microbiologica, 2003, 26, 91-100.

Puente S., Rubio J.M., Subirats M., Lago M., Gonzalez-Lahoz J. \& Benito A. The use of PCR in the diagnosis of hyperreactive malarial splenomegaly (HMS). Annals of Tropical Medicine and Parasitology, 2000, 94, 559-563.

Qari S.H., Shi Y.P., Goldman I.F., Udhayakumar V., Alpers M.P., Collins W.E. \& LAL A.A. Identification of Plasmodium vivax-like human malaria parasite. Lancet, 1993, 341, 780783.

Richardson D.C., Ciach M., Zhong K.J., Crandall I. \& Kain K.C. Evaluation of the Makromed dipstick assay versus PCR for diagnosis of Plasmodium falciparum malaria in returned travelers. Journal of Clinical Microbiology, 2002, 40, 4528-4530.

Rougemont M., Van SAanen M., Sahli R., Hinkikson H.P., Bille J. \& JATON K. Detection of four Plasmodium species in blood from humans by $18 \mathrm{~S}$ rRNA gene subunit-based and species-specific real-time PCR assays. Journal of Clinical Microbiology, 2004, 42, 5636-5643.
Rubio J.M., Benito A., Berzosa P.J., Roche J., Puente S., Subirats M., Lopez-Velez R., Garcia L. \& Alvar J. Usefulness of seminested multiplex PCR in surveillance of imported malaria in Spain. Journal of Clinical Microbiology, 1999, 37, 3260-3264.

Rubio J.M., Post R.J., van Leeuwen W.M., Henry M.C., LinDERGARD G. \& Hommel M. Alternative polymerase chain reaction method to identify Plasmodium species in human blood samples: the semi-nested multiplex malaria PCR (SnM-PCR). Transaction of the Royal Society of Tropical Medicine and Hygiene, 2002, 96 (Suppl. 1), S199-204.

Singh B., Kim Sung L., Matusop A., Radhakrishnan A., Shamsul S.S., Cox-Singh J., Thomas A. \& Conway D.J. A large focus of naturally acquired Plasmodium knowlesi infections in human beings. Lancet, 2004, 363, 1017-1024.

SMAlley M.E. \& Sinden R.E. Plasmodium falciparum gametocytes: their longevity and infectivity. Parasitology, 1977, $74,1-8$.

Speers D.J., Ryan S., Harnett G. \& Chidlow G. Diagnosis of malaria aided by polymerase chain reaction in two cases with low-level parasitaemia. Internal Medicine Journal, 2003, 33, 613-615.

Tham J.M., LeE S.H., TAN T.M., Ting R.C. \& Kara U.A. Detection and species determination of malaria parasites by PCR: comparison with microscopy and with ParaSight-F and ICT malaria Pf tests in a clinical environment. Journal of Clinical Microbiology, 1999, 37, 1269-1273.

Thellier M., Datry A., Alfa Cisse O., San C., Biligui S., Silvie O. \& DANIS M. Diagnosis of malaria using thick bloodsmears: definition and evaluation of a faster protocol with improved readability. Annals of Tropical Medicine and Parasitology, 2002, 96, 115-124.

Vo T.K., Bigot P., Gazin P., Sinou V., De Pina J.J., Huynh D.C., Fumoux F. \& PARZY D. Evaluation of a real-time PCR assay for malaria diagnosis in patients from Vietnam and in returned travellers. Transaction of the Royal Society of Tropical Medicine and Hygiene, 2007, 101, 422-428.

Whiley D.M., LeCornec G.M., Baddeley A., SAVIll J., Syrmis M.W., Mackay I.M., Siebert D.J., Burns D., Nissen M. \& SLOOTS T.P. Detection and differentiation of Plasmodium species by polymerase chain reaction and colorimetric detection in blood samples of patients with suspected malaria. Diagnostic Microbiology and Infectious Disease, 2004, 49, 25-29.

Wongsrichanalai C., Pornsilapatip J., Namsiripongpun V., Webster H.K., Luccini A., Pansamdang P., Wilde H. \& PraSITTISUK M. Acridine orange fluorescent microscopy and the detection of malaria in populations with low-density parasitemia. American Journal of Tropical Medicine and Hygiene, 1991, 44, 17-20. 